\title{
Znaczenie wiary dla wspólnoty małżeńskiej (Benedykt XVI do Trybunału Apostolskiego Roty Rzymskiej w 2013 roku)
}

Należało się spodziewać, że tegoroczne przemówienie rotalne, wygłoszone 26 stycznia 2013 roku przez papieża Benedykta XVI (19 kwietnia 2005 28 lutego 2013) w tak bardzo akcentowanym w Kościele Roku Wiary, będzie dotyczyło problematyki wiary nupturientów w relacji do zawieranego przez nich małżeństwa kanonicznego. Nikt natomiast nie spodziewał się, że będzie to ostatnie przemówienie do Trybunału Apostolskiego, ustępującego w niedługim czasie z urzędu „Zastępcy Chrystusa i Pasterza całego Kościoła tutaj na ziemi"' ${ }^{\prime}$, zgodnie z normą kanoniczną, Biskupa Rzymskiego ${ }^{2}$. Na marginesie warto zauważyć, że problematyka tejże alokucji nie jest nowym zagadnieniem teologiczno-prawnym, bowiem obecna jest ona tak w doktrynie kanonistycznej, jak i w orzecznictwie Trybunału Apostolskiego Roty Rzymskiej ${ }^{3}$.

Stąd też nie dziwi, że na samym początku swojej rotalnej alokucji z 2013 roku, po okolicznościowych słowach skierowanych do pracowników Roty

\footnotetext{
I Kan. $331 \mathrm{KPK}$.

2 Kan. $332 \$ 2$ KPK.

3 Zob. Decisio Melphicten.-Ruben.-Iuvenacen.-Terlitien., coram A. Stankiewicz, Decanus, Ponens, die 27 februarii 2004, [w:] Rotae Romanae Decisiones, t. 96, Libreria Editrice Vaticana 2012, s. 170-189.
} 
Rzymskiej, w szczególności do jej nowego dziekana P. V. Pinto, który w ubiegłym roku zastąpił na tym urzędzie zasłużonego dla rozwoju orzecznictwa rotalnego bp. A. Stankiewicza, Benedykt XVI powiedział: „w kontekście Roku Wiary, chciałbym zatrzymać się, w sposób szczególny, nad niektórymi aspektami relacji między wiarą a małżeństwem, wskazując, jak aktualny kryzys wiary, obecny w różnych częściach świata, niesie ze sobą kryzys wspólnoty małżeńskiej, wraz z całym bagażem cierpienia oraz kłopotów, które oddziałują także na potomstwo" ${ }^{4}$. Widzimy zatem, że Papież jest świadomy bardzo konkretnego kryzysu duchowego, który niestety niesie ze sobą wielopłaszczyznowe negatywne skutki w skali ogólnospołecznej, w szczególności zaś kryzys ten dotyczy w sposób bolesny wielu małżeństw oraz rodzin. Stąd też również w relacji do instytucji małżeństwa należałoby odnieść to, co papież Benedykt XVI napisał w liście apostolskim Porta fidei na temat znaczenia zwołanego Roku Wiary 5 .

1. Jako punkt wyjścia posłużyło Papieżowi wspólne źródło językowe, jakie w języku łacińskim posiadają dwa różne terminy: fides oraz foedus, przy czym ten ostatni w kan. $1055 \$ 1$ z Kodeksu prawa kanonicznego z 1983 roku opisuje naturalną rzeczywistość małżeństwa, jako nieodwołalnego przymierza między mężczyzną a kobietą ${ }^{6}$ - „wzajemne powierzenie się bowiem jest niezastąpioną bazą jakiegokolwiek paktu czy przymierza. Na płaszczyźnie teologicznej relacja między wiarą a małżeństwem przyjmuje znaczenie jeszcze głębsze. Węzeł małżeński bowiem, jako rzeczywistość naturalna, między ochrzczonymi został podniesiony przez Chrystusa do godności sakramentalnej” - o czym stanowi przywołana wcześniej norma kanoniczna ${ }^{7}$. Wczytując się w ten fragment przemówienia Benedykta XVI, trzeba stwierdzić, że akcentuje on obecność w małżeństwie dwóch rzeczywistości, naturalnej

4 www.vatican.va/holy_father/benedict_xvi/speeches/2013/january/documents/hf_ ben-xvi_spe_20130126_rota-romana_it.html (28.02.2013).

„W tej perspektywie Rok Wiary jest zachętą do autentycznego i nowego nawrócenia się do Pana, jedynego Zbawiciela świata. W tajemnicy Jego śmierci i zmartwychwstania Bóg objawił w pełni miłość, która zbawia i wzywa ludzi do przemiany życia przez odpuszczenie grzechów (por. Dz 5, 31)” (Benedykt XVI, List apostolski Porta fidei, nr 6).

6 „Matrimoniale foedus, quo vir et mulier inter se totius vitae consortium constituunt, ...” (kan. $1055 \$ 1 \mathrm{KPK})$.

7 www.vatican.va/holy_father/benedict_xvi/speeches/2013/january/documents/hf_benxvi_spe_20130126_rota-romana_it.html 
oraz nadprzyrodzonej, mówiąc inaczej możemy mówić o wymiarze prawnym oraz teologicznym instytucji małżeństwa. Takie spojrzenie na instytucję małżeństwa, to jeszcze jedno przywołanie przez Magisterium bogactwa normy kanonicznej, która z kolei posiada swoje bogate źródło nie tylko w Tradycji Kościoła, którą syntetycznie zbiera konstytucja Soboru Watykańskiego II Gaudium et spes ${ }^{8}$, ale także w starożytnej myśli prawnej’.

2. Sukcesywnie Benedykt XVI zwrócił uwagę, że nierozerwalny pakt (umowa) między mężczyzną a kobietą nie wymaga dla swojej sakramentalności osobistej wiary nupturientów, natomiast podkreślił, że wymaga jako warunek minimalny - intencję czynienia tego, czego wymaga Kościół. $\mathrm{Na}$ ten temat wyraźnie mówi kodeks Jana Pawła II z 1983 roku w kan. $1055 \$ 2^{10}$. Podobnie uczy wcześniejsza posynodalna adhortacja apostolska Familiaris consortio także Jana Pawła II z 1981 roku $^{11}$, ponadto istnieje stała doktryna Kościoła na temat niemożliwości rozdzielania między ochrzczonymi kontraktu oraz sakramentu ${ }^{12}$. Mówiąc na ten temat, Benedykt XVI odwołał się również do ważnego Dokumentu Międzynarodowej Komisji Teologicznej z 1977 roku dotyczącego sakramentalności małżeństwa, jak również zacytował to, co na ten temat powiedział dziesięć lat temu do Trybunału Roty Rzymskiej Jan Paweł II, który jednoznacznie stwierdził wówczas, że zachowanie nupturientów, które nie uwzględnia nadprzyrodzonego wymiaru małżeństwa, może spowodować jego nieważność tylko wtedy, kiedy będzie dotyczyło jego ważności na poziomie naturalnym, który jest podstawą

8 Konstytucja Gaudium et spes, nr 48.

9 "Nuptiae sunt coniunctio maris et feminae et consortium omnis vitae, divini et humani iuris comunicatio" (Iustiniani digesta, [in:] Corpus Iuris Civilis, editio stereotypa quinta, red. Th. Momsen, t. 1, Berlolini 1889, s. 1-873, tu: 23.2.1).

Io „Z tej racji między ochrzczonymi nie może istnieć ważna umowa małżeńska, która tym samym nie byłaby sakramentem” (kan. $1055 \$ 2$ KPK).

II „Wiara osób proszących o ślub kościelny może mieć różny poziom i pierwszym obowiązkiem pasterzy jest dopomóc w jej odkryciu, umocnieniu i doprowadzeniu do dojrzałości. Muszą oni także rozumieć racje, które skłaniają Kościół, że dopuszcza do obrzędu także tych, których usposobienie nie jest doskonałe. Wśród sakramentów małżeństwo ma tę cechę wyróżniającą je od innych, że jest sakramentem rzeczywistości już istniejącej w ekonomii zbawienia, że jest tym samym przymierzem małżeńskim, które zostało ustanowione przez Stwórcę od początku” (Adhortacja Familiaris consortio, nr 68).

${ }_{12}$ Zob. J. Hervada, Studi sull'essenza del matrimonio, Milano 2000, s. 347-364. 
dla jego sakramentalności ${ }^{13}$; przy czym Benedykt XVI wskazał wyraźnie, że problematyka ta, szczególnie w czasach współczesnych, wymaga dalszej refleksji. W ten sposób ukazał ważny obszar dla sukcesywnych badań teologiczno-prawnych na temat instytucji małżeństwa oraz sakramentalności związku między mężczyzną a kobietą.

3. Współczesna kultura, naznaczona przez subiektywizm oraz relatywizm etyczny oraz religijny, stawia osobę oraz rodzinę wobec pilnych wyzwań. $\mathrm{Na}$ pierwszym miejscu, jako ważne współczesne wyzwanie, Benedykt XVI wymienił kwestie dotyczące zdolności osoby ludzkiej w przedmiocie zobowiązania małżeńskiego na całe życie, czyli mówiąc inaczej podkreślił współczesne wątpliwości, czy jest to możliwe do zrealizowania oraz odpowiada naturze ludzkiej, czy też taki obraz instytucji małżeństwa nie kontrastuje z ludzką wolnością oraz jej autorealizacją. Odwołując się do swojego przemówienia do Kurii Rzymskiej z 21 grudnia 2012 roku, przypomniał, że częścią dzisiejszej rozpowszechnionej mentalności jest myślenie, że osoba staje się sobą, pozostając „autonomiczną” oraz gdy wchodzi w kontakt z innymi osobami jedynie poprzez relacje, które można przerwać w dowolnym momencie. W odpowiedzi na tak ukazane zagadnienie papież Benedykt XVI wyraźnie wskazał, że jedynie poprzez otwarcie na Bożą prawdę jest możliwe zrozumienie oraz realizowanie $\mathrm{w}$ konkretnym życiu małżeńskim oraz rodzinnym prawdy na temat człowieka jako syna Bożego, odnowionego poprzez chrzest św., zgodnie z tym, o czym czytamy w Janowej Ewangelii: „Kto trwa we Mnie, a Ja w nim, ten przynosi obfity owoc, ponieważ beze Mnie nic nie możecie uczynić"14. Tak nauczał Jezus swoich uczniów, wskazując na niezdolność realizowania jedynie przez człowieka tego, co jest konieczne dla osiąnnięcia prawdziwego dobra. Sukcesywnie odwołując się do swojego przemówienia do Międzynarodowej Komisji Teologicznej z 7 grudnia

\footnotetext{
I3 Jan Paweł II w swoim przemówieniu rotalnym z 2003 roku wskazał, między innymi: „Prawda ta nie może być zapominana w momencie wyznaczania granic dla wykluczenia sakramentalności (por. kan. $1101 \$ 2$ ) i błędu co do sakramentalnej godności małżeństwa (por. kan. 1099) jako ewentualnych tytułów nieważności. Dla wymienionych dwóch figur postanowiono, że zachowanie nupturientów, które nie zwraca uwagi na nadprzyrodzony charakter małżeństwa, może powodować jego nieważność tylko wtedy, jeżeli dotyczy jego ważności na płaszczyźnie naturalnej, na której jest położony sam znak sakramentalny" (T. Rozkrut, Jan Pawet II do Roty Rzymskiej, Tarnów 2003, s. 223, przypis nr 9).

I4 J 15, 5 .
} 
2012 roku, Benedykt XVI przypomniał, że odrzucenie Bożej propozycji prowadzi w rzeczywistości do głębokiego braku równowagi we wszystkich relacjach ludzkich, naturalnie łącznie z tą małżeńską, oraz wpływa na błędne zrozumienie mądrości i autorealizacji, które wraz z ucieczką od cierpliwego znoszenia cierpienia skazuje człowieka na zamknięcie się w swoim egoizmie oraz egocentryzmie. Przyjęcie wiary natomiast uzdalnia człowieka do daru z siebie samego dla innych, w szczególności dla swoich dzieci oraz swojej rodziny - o czym Benedykt XVI mówił także w swoim przywołanym już ubiegłorocznym przemówieniu do Kurii Rzymskiej ${ }^{15}$.

4. Wiara w Boga, wsparta Jego łaską, pozostaje bardzo ważnym elementem na drodze realizacji wzajemnego obdarowania oraz wierności małżeńskiej. Jednocześnie Benedykt XVI zaznaczył, że nie zamierza przez to wskazać, iż wierność, podobnie jak inne dobra małżeństwa, nie są możliwe w małżeństwie naturalnym, zawartym między osobami nieochrzczonymi. Albowiem także i ono nie jest pozbawione elementów, które pochodzą od Boga Stwórcy oraz włączają się w miłość oblubieńczą, która jednoczy Chrystusa i Kościół - jak uczy Międzynarodowa Komisja Teologiczna ${ }^{16}$. Jednakże zamknięcie na Boga lub odrzucenie wymiaru sakralnego małżeństwa oraz jego waloru w porządku łaski stwarza trudności w realizacji wymagającej koncepcji małżeństwa przekazywanej przez Kościół według obrazu Bożego, zwłaszcza wtedy, kiedy mamy do czynienia z odrzuceniem samego obowiązku wierności małżeńskiej lub innych elementów czy istotnych przymiotów małżeństwa, o czym jasno czytamy w normie kanonicznej na temat symulacji ${ }^{17}$. Chcąc jeszcze lepiej zobrazować przedstawioną doktrynę, Benedykt XVI odwołał się do myśli Tertuliana oraz Klemensa Aleksandryjskiego. W tym kontekście wskazał również, że święci, którzy przeżywali związek małżeński oraz rodzinny w perspektywie chrześcijańskiej, byli zdolni pokonać także sytuacje niesprzyjające, uświęcając przy tym współmałżonka i swoje dzieci, przede wszystkim poprzez miłość

\footnotetext{
Is Zob. Allocuzione alla Curia Romana, „L'Osservatore Romano”, 22 XII 2012, s. 4.

i6 Zob. La dottrina cattolica sul sacramento del matrimonio, [w:] Commissione Teologica Internazionale, Documenti 1969-2004, Bologna 2006, s. 143-146.

${ }^{17}$ „Jeśli jednak jedna ze stron albo obydwie pozytywnym aktem woli wykluczyłyby samo małżeństwo lub jakiś istotny element małżeństwa, albo jakiś istotny przymiot, zawierają je nieważnie" (kan. $1101 \$ 2 \mathrm{KPK})$.
} 
wzmacnianą mocnym zaufaniem Bogu, szczerą pobożnością religijną oraz intensywne życie sakramentaln ${ }^{18}$.

5. Sukcesywnie papież Benedykt XVI wskazał, że pragnie krótko zatrzymać się nad bonum coniugum. Wskazał, że wiara jest ważna w realizacji autentycznego dobra małżonków, które istnieje przede wszystkim w pragnieniu, zawsze i wszędzie, dobra drugiej osoby, pozostającego w funkcji realizacji prawdziwego oraz nierozerwalnego consortium vitae. W rzeczywistości bowiem przeżywanie prawdziwej communio coniugalis związane jest z dynamizmem wiary, stąd też jej wyznawanie, szczera odpowiedź osobista wiąże wierzącego z gestem miłości Pana Boga ${ }^{19}$. We wspólnocie małżeńskiej wiara wpływa bowiem na rozwój oraz owocowanie miłości małżonków, otwierając tym samym na obecność w ich wspólnocie Trójjedynego Boga oraz czyniąc samo życie małżeńskie, tak przeżywane, „radosną nowiną” wobec świata. Zaraz potem Benedykt XVI stwierdził, że rozumie trudności, tak z punktu widzenia prawnego, jak i praktycznego, w wyliczaniu elementów istotnych związanych z bonum coniugum, rozumianych dotychczas przede wszystkim w relacji do hipotezy niezdolności, o której mówi kan. 1095 Kodeksu prawa kanonicznego z 1983 roku. Bonum coniugum, wskazał Papież, posiada także znaczenie, kiedy jest mowa o symulacji zgody małżeńskiej, który jako tytuł nieważności zgody małżeńskiej może występować obok tradycyjnego modelu trzech augustyńskich dóbr małżeńskich, obecnych od dawna w orzecznictwie rotalnym ${ }^{20}$.

6. Kończąc swoją alokucję rotalną, papież Benedykt XVI wskazał, że swoimi rozważaniami nie pragnie sugerować żadnego automatycznego związku pomiędzy brakiem wiary a nieważnością związku małżeńskiego, ale raczej chcie wskazać, w jaki sposób taki brak mógłby, jakkolwiek niekoniecznie, szkodzić także dobrom małżeństwa, od momentu, w którym odniesienie do porządku naturalnego zaplanowanego przez Boga jest związane z paktem małżeńskim ${ }^{21}$.

\footnotetext{
I8 www.vatican.va/holy_father/benedict_xvi/speeches/2013/january/documents/hf_ ben-xvi_spe_20130126_rota-romana_it.html

I9 Tamże.

20 Tamże.

2I Tamże.
} 
Podsumowując, należałoby powiedzieć, że mamy do czynienia z bardzo bogatym przemówieniem, które zawiera nie tylko elementy doktrynalne, ale także praktyczne, przede wszystkim, gdy idzie o orzekanie nieważności małżeństwa przez Kościół. Naturalnie należy także podkreślić znaczenie elementów praktycznych związanych tak z opieką duszpasterską nad małżeństwami w kryzysie, jak i może jeszcze bardziej, wezwaniem do poprawnego formowania przyszłych małżonków. Ponadto przemówienie to otwiera także nowe przestrzenie dla refleksji naukowej, która niewątpliwie zostanie podjęta poprzez studium na bogactwem Magisterium papieża Benedykta XVI. 
